\title{
Self-regulated learning mahasiswa pendidikan guru Sekolah dasar (PGSD) tahun pertama
}

\author{
Darmiany \\ Bimbingan dan Konseling, FKIP Universitas Mataram \\ Email: anikdarmiany@yahoo.co.id
}

(Diterima: 20-Mei-2016; di revisi: 12-Juni-2016; dipublikasikan: 28-Juni-2016)

\begin{abstract}
The research is aimed to measure the comprehension level toward regulated learning of the students who are in the first year of prospective teacher related with the GPA (Grade Point Average) achieved. The research applied desciptive research method, and the data collection was done using survey towards 75 students which is $13 \%$ percents from the population, the PGSD Semester II students in FKIP of Semarang University. The findings showes that comprehension level of SRL of the PGSD students who are in their first year was $72 \%$ (the comprehension level of SRL was high), and there were positive effect between self-regulated learning (SRL) and GPA (Grade point Average) of the students. The higher the comprehension level towards the SRL the higher GPA will be achieved.
\end{abstract}

Keywords: Self-Regulated Learning; GPA (Grade Point Average); PGSD students

\begin{abstract}
Abstrak. Penelitian ini bertujuan untuk mengukur tingkat pemahaman self regulated learning mahasiswa calon guru tahun pertama yang dikaitkan dengan indeks prestasi yang diperoleh. Penelitian dilaksanakan dengan menggunakan metode deskriptif, dan teknik pengumpulan datanya dilakukan dengan teknik survai terhadap 74 mahasiswa (13\%) dari populasi mahasiswa PGSD semester II FKIP Universitas Mataram. Hasil penelitian menunjukkan bahwa tingkat pemahaman SRL mahasiswa PGSD tahun pertama adalah $72 \%$ (pemahaman SRL tinggi), dan terdapat pengaruh yang positif antara self regulated learning (SRL) dengan indek prestasi akademik (IP) mahasiswa. Semakin tinggi tingkat pemahaman mahasiswa terhadap SRL maka akan semakin tinggi pula IP yang akan dicapai.
\end{abstract}

Keyword: Self-regulated learning; indeks prestasi; mahasiswa PGSD

Copyright $\odot 2017$ Universitas Negeri Makassar. This is an open access article under the CC BYNC-ND license (http://creativecommons.org/licenses/by-nc-nd/4.0/).

\section{PENDAHULUAN}

Tahun pertama perkuliahan merupakan suatu periode transisi, yaitu suatu periode dimana seorang mahasiswa masih menyesuaikan perubahan baik dalam sistem pembelajaran maupun lingkungan baru, dari lingkungan SMA ke lingkungan perguruan tingi. Dalam periode ini, seorang mahasiswa masih menunjukkan dan

menerapkan perilaku belajar seperti ketika berada di sekolah menengah (SMA). Kebanyakan dari mereka belum memiliki kesiapan belajar secara mandiri sebagaimana dibutuhkan di perguruan tinggi. Kontrol terhadap aktivitas belajarpun sangat kurang sehingga dapat berakibat pada kegagalan dalam memperoleh prestasi akademik 
yang optimal bila tidak segera diantisipasi. Mahasiswa sebenarnya memiliki banyak waktu luang untuk belajar, namun tidak dipergunakan sebaik-baiknya untuk belajar. Mereka lebih banyak menghabiskan waktu untuk menonton $\mathrm{TV}$, main game, dan masih banyak kegiatan lain yang kurang membawa manfaat. Mahasiswa juga memiliki kecenderungan menerapkan sistem belajar SKS (sistem kebut semalam). Salah satu faktor penyebab perilaku belajar "SKS" adalah orientasi belajar yang hanya ingin "lulus" ujian. Dengan hanya "lulus", maka mahasiswa merasa tidak perlu lagi mengulang pelajaran yang sudah disampaikan (Hanif, 2008).

Permasalahan lain yang dihadapi mahasiswa adalah bahwa sejak awal nilai (score) yang diperoleh digunakan sebagai sebuah parameter yang akan menunjukkan tingkat kepahaman dalam pokok bahasan tertentu. Namun kenyataannya, banyak terjadi ketidaksinkronan. Artinya bahwa nilai yang menjadi standar acuan itu tak lagi representatif untuk mendeskripsikan pencapaian hasil belajar mahasiswa, karena belajar hanya menjadi hafalan jangka pendek yang berguna untuk ujian saja, dan menyontek dianggap bagian dari usaha bukan sesuatu yang memalukan yang secara signifikan berpengaruh secara psikologis bagi mahasiswa.

Untuk mengatasi permasalahan seperti tertulis tersebut di atas, mahasiswa membutuhkan self-regulated learning (SRL) dalam belajar. SRL dibutuhkan mahasiswa agar mereka mampu mengatur dan mengarahkan dirinya sendiri, mampu menyesuaikan dan mengendalikan diri, terutama bila menghadapi tugas-tugas yang sulit, serta mencapai indeks prestasi tinggi melalui usaha-usaha yang jujur dan bertanggung jawab. Mahasiswa yang memiliki self-regulated learning rendah tidak mampu mengorganisasikan dan mengatur diri sendiri, sehingga mahasiswa dengan self-regulated learning yang rendah cenderung memiliki perilaku belajar yang asal asalan, tidak memiliki perencanaan dan tujuan yang jelas dalam belajar (Wangid, 2006:12).

Berbagai penelitian telah menunjukkan bahwa self regulated learning (SRL) memiliki kontribusi penting bagi peningkatan kinerja belajar mahasiswa. Oleh karena itu, mendorong mahasiswa belajar selaras dengan prinsip self regulated learning menjadi penting. SRL melibatkan komponen kognitif, afektif, motivasi, dan perilaku yang memungkinkan individu menyesuaikan tujuan dan usaha mereka untuk mencapai hasil yang diinginkan, sesuai tuntutan lingkungan yang terus mengalami perubahan.

Konsep self-regulated learning (SRL) merupakan konsep yang berkembang oleh Bandura (mukhid, 2009) dan telah menjadi fokus perhatian penelitian dalam kajian psikologi pendidikan (Pintrich dalam Montalvo \& Torres, 2004). Konsep SRL disajikan sebagai sebuah kerangka komprehensif untuk memahami proses yang berperan penting dimana pebelajar merupakan seorang agen aktif dalam proses belajarnya sendiri. Selanjutnya Mentalvo \& Torres (2004) menambahkan bahwa SRL sebagai proses konstruktif aktif, dimana pebelajar merancang tujuan belajar dan kemudian berupaya untuk memantau, mengatur dan mengontrol kognisi, motivasi dan perilaku mereka, agar sesuai dengan tujuannya dan kondisi kontekstual dari lingkungannya.

Belajar berdasar regulasi diri adalah proses proaktif dan sadar yang digunakan oleh siswa untuk mengendalikan proses pembelajarannya sendiri dalam bentuk kognisi, motivasi, dan perilaku dan bukan proses reaktif siswa yang secara impersonal berkehendak untuk meraih prestasi (Zimmerman, 2008).

SRL merupakan suatu bentuk pembelajaran yang efektif, terjadi proses mahasiswa menyusun tujuan, memonitor, mengontrol, meregulasi kognisi, motivasi dan perilakunya, dan direfleksikan dalam proses belajarnya (Yetkin, 2006).

Belajar dalam self-regulated learning, memerlukan 'kemauan' sekaligus 'keterampilan'. Melalui proses tersebut, para mahasiswa belajar secara aktif dalam arti didorong oleh kemauan internal diri mereka dan terarah pada suatu pencapaian tujuan. Untuk menjadi mahasiswa yang berhasil dan berprestasi, maka seorang mahasiswa harus menjadi pembelajar yang mandiri. Pembelajar yang mandiri mengimplikasikan kemampuan bagi mahasiswa yang bersangkutan untuk mengontrol proses belajar mereka sendiri (Auwalu \& Norsuhaily, 2015). Keterampilan pengaturan diri (selfregulation) ini memiliki peran penting dalam keberhasilan seorang mahasiswa (Heikkila \& Lonka, 2006; Nicol \& Macfarlane-Dick, 2006). Akan tetapi, Allgood, Risko, Alvarerez, dan Fairbank (2000) menyatakan bahwa mayoritas mahasiswa yang menempuh pendidikan tinggi 
ternyata tidak siap menghadapi tantangan dalam sistem perguruan tinggi.

SRL penting bagi semua jenjang akademis. SRL dapat dilakukan sejak tahap pendidikan dasar untuk membantu siswa memperoleh kemampuan mengatur diri dalam kegiatan belajar. Veenman, Beems, Gerrits dan Weeghs (Abdullah, 2007) memandang bahwa SRL merupakan suatu hal yang penting tidak hanya dalam mengarahkan pembelajaran mahasiswa selama di kampus, tetapi juga untuk self-education dan memperbaharui pengetahuan mahasiswa setelah lulus dari perguruan tinggi.

$$
\text { Secara kontekstual penelitian }
$$

dilaksanakan di tingkat pendidikan tinggi khususnya pada program kependidikan. Pengambilan tingkat pendidikan tinggi pada program kependidikan ini didasari pemikiran bahwa individu-individu yang lulus dari pendidikan ini adalah calon guru, sehingga harus merupakan manusia pelopor yang memiliki kemandirian dalam menghadapi masa depan dan menjadi teladan bagi murid-muridnya.

Permasalannya adalah seberapa besar pemahaman mahasiswa terhadap SRL, bagaimana hubungan dan pengaruh tingkat pemahaman SRL terhadap IP mahasiswa PGSD FKIP Unram, sehingga tujuan dari penelitian ini adalah untuk mengetauhi besarnya tingkat pemahaman mahasiswa terhadap SRL, dan hubungan dengan pencapaian indek prestasi, serta pengaruh tingkat pemahaman SRL terhadap IP mahasiswa PGSD FKIP Unram.

Berdasarkan uraian-uraian di atas, maka hipotesis yang diajukan dalam penelitian ini, sebagai berikut: (1) tingkat pemahaman mahasiswa terhadap SRL berpengaruh terhadap IP, (2) hubungan antara pemahaman selfregulated learning dengan indek prestasi (IP) mahasiswa

\section{METODE}

Penelitian ini dilaksanakan dengan metode deskriptif, dan teknik pengumpulan datanya dilakukan dengan teknik survei. Pengumpulan data tersebut dilakukan melalui wawancara langsung kepada responden dengan menggunakan daftar pertanyaan berdasarkan instrumen dalam bentuk skala yang telah dipersiapkan sebelumnya.

Subjek dalam penelitian ini adalah mahasiswa yang masih aktif kuliah di Fakultas
Keguruan dan Ilmu Pendidikan Universitas Mataram (FKIP Unram) pada program studi PGSD yang berada di semester II sebanyak \pm 580 orang mahasiswa. Jumlah responden ditentukan sebanyak 74 mahasiswa (13\%) dari jumlah mahasiswa semester II pada program studi PGSD. Penentuan jumlah mahasiswa sebagai responden sebanyak (13\%) tersebut didasarkan pada penentuan jumlah subjek dalam penelitian yang didasarkan pada teori yang dikemukakan oleh Arikunto (2010) yang menyebutkan bahwa jika populasi $\leq 100$ orang maka semua dijadikan sampel dalam penelitian, namun jika populasi $>100$ orang maka penarikan jumlah sampel dilakukan dengan sistem persentase, mulai dari 10\% - 15\%, 20\% - 25\% keatas. Jumlah sampel ditetapkan sebanyak 13\% dari 580 mahasiswa atau sama dengan $13 \%$ x 580 $=74$ orang mahasiswa.

Sehubungan dengan tujuan penelitian maka data yang dikumpulkan berupa data kuantitatif berupa IP dan data kualitatif yang menggambarkan tentang tingkat pemahaman mahasiswa terhadap SRL. Pengukuran SRL menggunakan MSLQ yang diadaptasi dari instrumen self regulated learning yang disusun oleh Pintrinch, Smith, Garcia \& McKeachine (dalam Duncan \& McKeachie, 2005) dan diberi nama The Motivated Strategies for Learning Questionnaire (MSLQ). MSLQ terdiri dari 75 item, dan terbagi menjadi dimensi motivasi dan dimensi learning strategies. MSLQ dirancang untuk mengukur orientasi motivasional siswa dan penggunaan strategi belajar yang didasarkan pada pandangan kognitif. Alat ukur ini berbentuk self report dimana mahasiswa mempersepsikan dirinya sendiri terhadap motivasi dan penggunaan SRL-nya. MSLQ terdiri dari dua dimensi utama, yaitu motivasi dan learning strategies. Masing-masing dimensi terbagi lagi menjadi beberapa subskala, yaitu dimensi motivasi terdiri dari intrinsic goal orientation, extrinsic goal orientation, task value, control of learning beliefs, self efficacy, dan test anxiety. Sedangkan dimensi learning strategies terdiri dari rehearsal, elaboration, organization, critical thinking, metacognitive self regulation, time \& study environment management, effort regulation, peer learning, dan help seeking. Skala regulasi strategi belajar memiliki koefisien korelasi antara 0,344 hingga 0,719 dengan nilai $\alpha$ (Cronbach Alpha) sebesar 0,951). Berdasarkan hasil analisis tersebut dapat disimpulkan bahwa 
alat ukur tersebut reliabel dalam pengukurannya, dan layak digunakan.

Alat analisis yang digunakan sesuai dengan tujuan dari penelitian ini adalah analisis regresi sederhana, yang dirumuskan : $\mathrm{Y}=\mathrm{a}+$ $\mathrm{bX}$, dimana $\mathrm{Y}$ adalah variabel tergantung (dependent variabel) yaitu berupa IP mahasiswa, dan $\mathrm{X}$ adalah variabel bebas (independent variabel) yaitu berupa tingkat pemahaman mahasiswa tentang SRL.

Variabel tentang IP didasarkan pada penyelenggaran pendidikan dengan menggunakan sistem kredit semester, dimana IP dari mahasiswa akan berada pada kisaran $\geq 0$ sampai dengan $\leq 4$. Adapun variabel tentang pemahaman mahasiswa terhadap SRL diperhitungkan dengan jumlah dari skor yang dicapai mahasiswa dalam pemahaman SRL. Untuk mengukur skor SRL tersebut dilakukan dengan menjumlahkan skor dari seluruh istrumen dari SRL yang jumlahnya sebanyak 75 item, dengan nilai skor masing-masing item adalah 1 , 2, 3, dan 4. Dengan demikian nilai terendah dari skor tentang SRL tersebut adalah sebesar 75, dan skor yang tertinggi adalah 300 . Secara lebih rinci dari tingkat pemahaman SRL tersebut dikelompokkan menjadi lima kriteria, yaitu :

Tabel 1: Pengelompokan Tingkat Pemahaman SRL

\begin{tabular}{cc}
\hline Tingkat Pemahaman SRL & Kriteria \\
\hline $75-120$ & Sangat Rendah \\
\hline $121-165$ & Rendah \\
\hline $166-210$ & Sedang \\
\hline $211-255$ & Kuat \\
\hline $256-300$ & Sangat Kuat \\
\hline
\end{tabular}

\section{HASIL DAN PEMBAHASAN}

Deskripsi data penelitian tentang tingkat pemahaman dan pengaruh SRL terhadap prestasi akademik mahasiswa (IP) setelah dilakukan skoring dan diolah dengan SPSS 16.0 for windows diperoleh gambaran sebagai berikut :

Tabel 2. Descriptive Statistics

\begin{tabular}{lccccc}
\hline & N & Minimum & Maximum & Mean & Std. Deviation \\
\hline IPK & 74 & 2,43 & 3,79 & 3,16 & 0.336 \\
\hline SRL & 74 & 171 & 265 & 215 & 21.879 \\
\hline
\end{tabular}

Pada Tabel 2 tersebut di atas terlihat bahwa secara umum menggambarkan SRL ternyata sangat bervariasi. Ini terlihat dari rentang skor yang diperoleh bergerak dari 171 hingga 265 dengan rata-rata 215. Berdasarkan kriteria dalam tingkat pemahaman SRL seperti telah dikemukakan di atas, maka capaian SRL mahasiswa PGSD termasuk dalam kriteria tingkat pemahaman tinggi. Hal ini dimungkinkan karena berdasarkan gambaran tentang penerimaan mahasiswa Program PGSD di Universitas Mataram, mahasiswa yang diterima adalah mahasiswa yang mampu bersaing dan menyisihkan calon mahasiswa lainnya dengan perbandingan $1: 150$. Perbandingan yang begitu besar tersebut disebabkan karena minat lulusan
Sekolah Menengah Tingkat Atas di Propinsi NTB begitu besar, khususnya dalam lima tahun terakhir. Sedangkan skor indeks prestasi akademik (IPK) bergerak antara 2,43 sampai dengan 3,79 dengan rata 3,16.

Permasalahan lain yang memiliki konstribusi pada kecenderungan mahasiswa memiliki tingkat pemahaman regulasi diri dalam belajar tinggi adalah motivasi, diprediksi bahwa mahasiswa yang berhasil lulus menjadi mahasiswa PGSD di FKIP Unram Tahun Ajaran 2015-2016, adalah mahasiswa yang memiliki motivasi yang kuat untuk menjadi pendidikik atau guru SD. Menurut (Tavakolizadeh \& Qavam, 2011) bahwa motivasi dalam belajar sangat membantu dalam mengembangkan 
adaptasi keyakinan yang sesuai, sehingga pada kondisi tersebut akan memudahkan mahasiswa dalam mengerjakan tugas-tugas akademik secara mandiri tanpa hambatan yang berarti.

Hasil analisis dengan menggunakan SPSS memberikan penafsiran terhadap koefisien korelasi yang ditemukan tersebut besar atau kecil, dapat dilihat pada tabel penafsiran koefisien korelasi. Berikut ini tabel penafsiran koefisien korelasi (Sugiyono, 2014) :

Tabel 3. Penafsiran Koefisien Korelasi

\begin{tabular}{cc}
\hline Interval Koefisien & Tingkat Hubungan \\
\hline $\mathbf{0 , 0 0}-\mathbf{0 , 1 9 9}$ & Sangat Rendah \\
$\mathbf{0 , 2 0}-\mathbf{0 , 3 9 9}$ & Rendah \\
\hline $\mathbf{0 , 4 0}-\mathbf{0 , 5 9 9}$ & Sedang \\
\hline $\mathbf{0 , 6 0}-\mathbf{0 , 7 9 9}$ & Kuat \\
\hline $\mathbf{0 , 8 0}-\mathbf{1 , 0 0}$ & Sangat Kuat \\
\hline
\end{tabular}

Berdasarkan hasil analisis dalam penelitian ini, besarnya korelasi antara SRL dengan Indek Prestasi Mahasiswa program Studi PGSD pada FKIP Unram adalah sebesar 0,277. Untuk uji korelasi antara SRL dengan
IP mahasiswa dilakukan dengan menggunakan tingkat signifikansi sebesar 5\%. Secara lengkap dari analsisis tentang korelasi tersebut dapat dilihat pada tabel 4 berikut :

Tabel 4. Tingkat Korelasi antara SRL dengan IPK

\begin{tabular}{|c|c|c|c|}
\hline \multirow{3}{*}{$\begin{array}{l}\text { Pearson } \\
\text { Correlation }\end{array}$} & & IPK & SRL \\
\hline & IPK & 1.000 & .277 \\
\hline & SRL & .277 & 1.000 \\
\hline \multirow[t]{2}{*}{ Sig. (1-tailed) } & IPK & . & .008 \\
\hline & SRL & .008 & . \\
\hline \multirow[t]{2}{*}{$\mathbf{N}$} & IPK & 74 & 74 \\
\hline & SRL & 74 & 74 \\
\hline
\end{tabular}

Pada tabel 4 dapat dilihat bahwa hubungan atau korelasi antara SRL dengan Indek Prestasi Mahsiswa adalah sebesar 0,277 bertanda positif dan signifikan pada taraf nyata $5 \%$. Berdasarkan tabel penafsiran koefisien korelasi di atas, maka nilai koefisien korelasi 0,227 berada pada interval koefisien 0,20 - 0,399 yang berarti ada hubungan namun berada pada tingkat hubungan yang rendah. Koefisien korelasi bertanda positif berarti terdapat hubungan positif antara kedua variabel, artinya semakin tinggi tingkat pemahaman mahasiswa terhadap SRL maka akan semakin tinggi pula IP yang akan dia capai. Jadi terdapat hubungan antara self- regulated learning dengan prestasi akademik mahasiswa PGSD FKIP Unram.

Penelitian yang dilakukan ini menunjukkan hasil dimana semakin tinggi tingkat kemampuan SRL maka semakin tinggi pula prestasi yang mampu diraih mahasiswa. Self-regulated learning merupakan aspek penting dari prestasi akademik mahasiswa (Hofer, Yu, \& Pintrich, 1998; Pintrich \& De Groot, 1990).

Hasil uji statistik tentang pengaruh SRL terhadap IP mahasiswa dengan menggunakan model regresi linear sederhana disajikan dalam tabel Summary berikut. 
Tabel 5. Hasil Analisis Regresi $(Y=a+b X)$

\begin{tabular}{|c|c|c|c|c|c|}
\hline \multicolumn{6}{|c|}{ Coefficients $^{a}$} \\
\hline \multirow[t]{2}{*}{$\begin{array}{c}\text { Model } \\
1\end{array}$} & \multicolumn{2}{|c|}{ Unstandardized Coefficients } & \multirow{2}{*}{$\begin{array}{c}\begin{array}{c}\text { Standardized } \\
\text { Coefficients }\end{array} \\
\text { Beta }\end{array}$} & \multirow{2}{*}{$\mathbf{T}$} & \multirow{2}{*}{ Sig. } \\
\hline & $\mathrm{B}$ & Std. Error & & & \\
\hline (Constant) & 2.25 & .429 & & 5.992 & .000 \\
\hline SRL & .004 & .002 & .261 & 2.450 & .017 \\
\hline
\end{tabular}

Dependent Variable: IPK

Dijelaskan dalam tabel 5 di atas bahwa dari hasil analisis tersebut maka dapat dirumuskan tentang fungsi regresi sedehana yang menggambarkan pengaruh dari SRL terhadap IP mahasiswa PGSD di FKIP Unram adalah : $\mathrm{Y}=$ $2,25+0,004 \mathrm{X}$. Model tersebut menunjukkan bahwa besarnya constanta (intersef) adalah sebesar 2,25, dan besarnya koefisien regresi adalah sebesar 0,004. Ini berarti bahwa pengaruh SRL terhadap IP relatif kecil, yaitu setiap peningkatan SRL sebesar 10 satuan hanya akan meningkatkan IP sebesar 0,04.

Pada tabel 5, di atas dapat juga dilihat bahwa berdasarkan hasil analisis regresi diketahui besarnya $R^{2}$ adalah 0,077 dan $R$ sebesar 0,227. Ini berarti secara statistik model yang digunakan tersebut hanya sedikit sekali dapat menjelaskan bagaimana pengaruh faktor dari SRL terhadap IP mahasiswa, yaitu hanya sekitar 7\% saja, sedangkan sisanya yang terbesar (93\%) adalah dipengaruhi oleh faktor lain yang tidak dimasukkan dalam model tersebut.

Walaupun demikian dari analisis regresi tersebut diketahui pula bahwa constanta (intersef) dari hasil regresi tersebut adalah sebesar 2,25 dan ini signifikan pada taraf nyata 5\%. Artinya adalah seandainya mahasiswa tersebut belum memamahai tentang SRL, mereka sudah dapat mencapai IP sebesar 2,25. Selanjutnya untuk koefisien regrsesi dari SRL adalah sebesar 0,004 dan signifikan pada taraf nyata $5 \%$, ini artinya bahwa semakin tinggi pemahaman mahasiswa terhadap SRL akan dapat meningkatkan IP dari mahasiswa tersebut. Sebagai ilustrasi dari pengaruh SRL terhadap IP mahasiswa tersebut secara grafik dapat digambarkan sebagai berikut dalam gambar:

Gambar 1: Grafik Pengaruh SRL dengan IPK

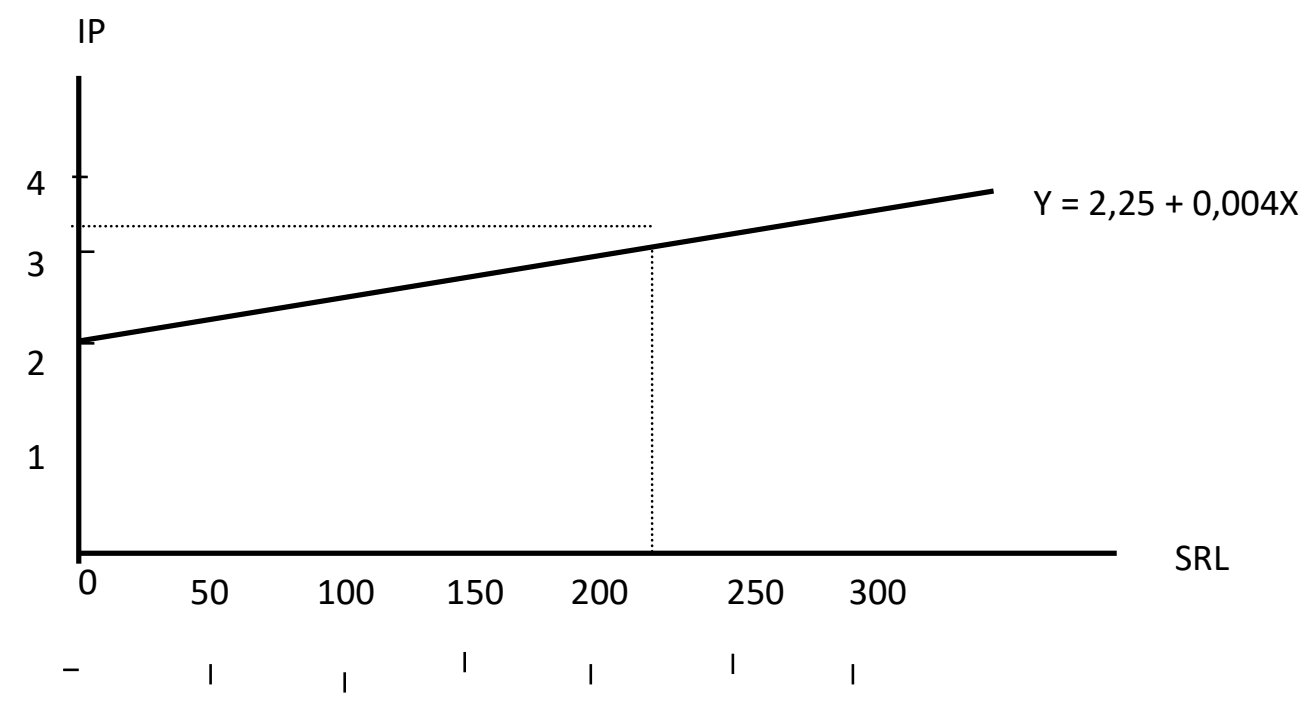

Pada gambar grafik tersebut di atas dapat dilihat bahwa apabila SRL sebesar 0 maka IP yang dicapai oleh mahasiswa adalah sebesar 2,25. dan apabila SRL-nya sebesar 215 maka IP yang dicapai oleh Mahasiswa sebesar 3,16.

Pengaruh pemahaman SRL terhadap IP sebesar 0,004 tersebut relatif kecil, dan dalam grafik terlihat kemiringan garis regresinya yaitu $\mathrm{Y}=2,25+0,004 \mathrm{X}$ adalah sangat landai. Pengaruh yang relatif kecil ini kemungkinan 
disebabkan karena mahasiswa baru pada taraf pemahaman tentang SRL, belum sampai pada taraf mengimplementasikan ke dalam kegiatan belajarnya.

Penjelasan tersebut di atas, senada dengan pendapat Zimmerman, (Auwalu \& Norsuhaily, 2015) bahwa SRL adalah pengetahuan potensial yang dimiliki individu untuk meningkatkan prestasi akademik, merancang strategi belajar, menentukan langkahlangkah yang dapat dilakukan untuk mencapai tujuan belajar, serta mengevaluasi keberhasilan dan kekurangan yang diperoleh dalam belajar. Wilson dalam Wangid (2006), menjelaskan bahwa SRL bila dilatihkan kepada mahasiswa, dan kemudian mahasiswa menerapkannya dalam belajar, maka SRL ini mempunyai pengaruh yang signifikan (besar).

Seorang pebelajar (mahasiswa) dituntut mampu meregulasi diri sendiri, meregulasi perilaku, dan lingkungan. Ketiga proses regulasi digambarkan sebagaimana tampak pada gambar 2.

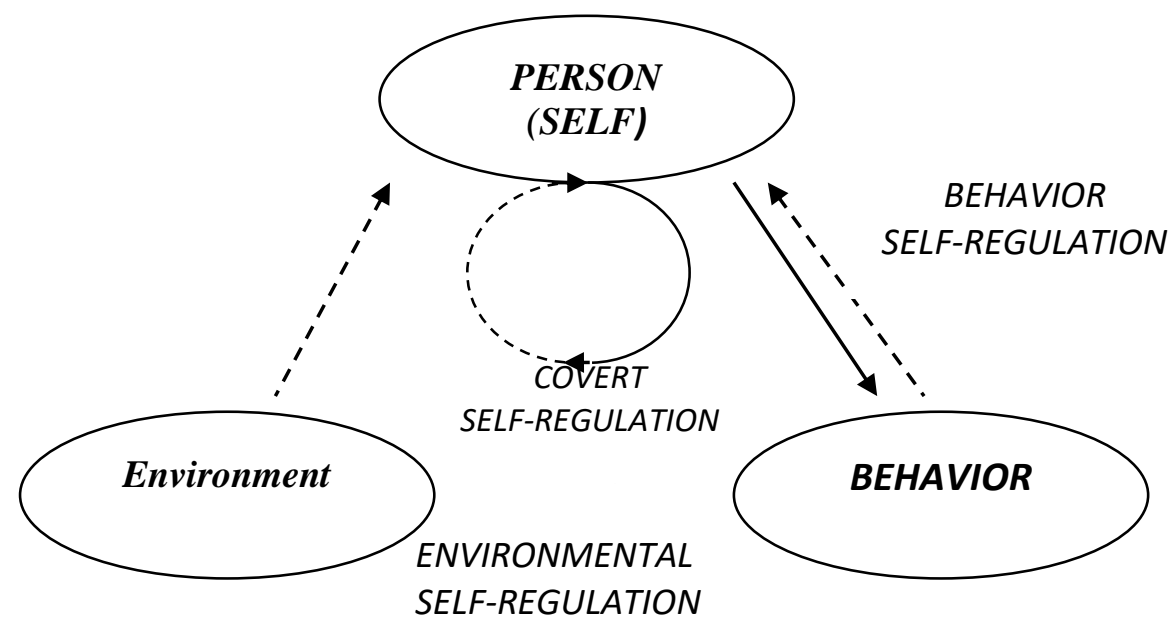

Keterangan:

Strategy Use
Enactive Feedback

Gambar 2. Regulasi Diri dalam Kaitannya dengan Triadic Recipricality

Dalam gambar tersebut ditunjukkan bahwa proses regulasi diri merupakan proses internal yang tidak tampak (tersembunyi) yang secara timbal balik mempengaruhi antara satu faktor dengan faktor lainnya yang terjadi pada diri (covert self regulation). Misalnya efek dari proses metakognitif pada proses personal lainnya untuk meningkatkan kemampuan dalam mengingat sesuatu digunakan teknik nemoteknik. Hasil proses regulasi selanjutnya diwujudkan dalam bentuk perilaku dan perilaku tersebut diregulasi untuk mencapai suatu tujuan (behavior self-regulation).misalnya selalu mengecek tugas akademik, hal ini akan memberikan informasi tentang ketepatan pengerjaan tugas. Perilaku muncul dalam seting lingkungan, guna mencapai suatu tujuan yang diharapkan maka seting lingkungan diregulasi sedemikian rupa sehingga memungkinkan individu mencapai kinerja yang terbaik (environmental self-regulation).

Self-regulated learning memiliki peranan penting dalam pencapaian hasil akademik yang optimal. Sebagaimana disimpulkan oleh Gie (dalam mudarrisa, 2014) bahwa terdapat beberapa syarat bagi mahasiswa untuk mencapai kesuksesan akademik salah satunya adalah pengaturan diri, yakni pengaturan sebaik- baiknya terhadap pikiran, tenaga, waktu dan semua sumber daya lainnya dalam belajarnya.

Pengaruh self-regulated learning terhadap prestasi belajar dapat pula dilihat dalam 
penelitian sebelumnya yang dilakukan oleh Sunawan (2003) ditemukan bahwa individu yang menerapkan selfregulated learning dalam belajar bidang studi matematika memperoleh hasil belajar yang lebih tinggi dibandingkan individu yang tidak menerapkan self-regulated learning dalam matematika. Dengan demikian dapat disimpulkan bahwa self-regulated learning memiliki peran penting dalam meningkatkan prestasi akademik mahasiswa di perguruan tinggi bahwa memang tingkat IP yang dicapai oleh mahasiswa dipengaruhi oleh banyak faktor, diantaranya adalah faktor internal dan faktor eksternal. Faktor internal, yakni faktor yang berasal dari dalam diri mahasiswa dan faktor eksternal yang merupakan faktor dari luar diri mahasiswa.

Dalam penelitian ini, masih dalam tahap pemahaman kosep, bahwa sebenarnya mahasiswa telah melakukan self-regulated learning yang melibatkan kemampuan metakognitif, motivasi dan perilaku aktif merupakan faktor internal yang mempengaruhi prestasi akademik mahasiswa, hanya saja sebagaian besar mahasiswa belum mengerti bahwa yang mereka lakukan adalah SRL. Berdasarkan penjelasan-penjelasan yang telah dikemukakan di atas, dapat disimpulkan bahwa keberhasilan mahasiswa dalam mencapai prestasi akademik yang optimal dipengaruhi oleh berbagai faktor, yang salah satunya adalah self-regulated learning.

Individu memiliki otonomi dalam dirinya untuk memilih, menyusun dan menciptakan lingkungan sosial dan fisik seimbang dalam mencapai belajar yang optimal.

Sebagaimana Peverly, dkk. (2003) menggambarkan bahwa individu yang melakukan self-regulated learning adalah individu yang memiliki pengetahuan dan tujuan strategis serta memiliki kemandirian untuk mengerahkan kemampuannya secara efektif dalam belajar.

Melalui strategi self-regulated learning diasumsikan mahasiswa mampu menempuh proses pendidikan dan indek prestasi akademik dengan optimal (Butler dan Winne dalam sudirman, 2015).

Selain pengaruh faktor internal dalam proses dan keberhasilan akademik, mahasiswa juga dipengaruhi oleh faktor eksternal. Faktor eksternal yang berasal dari lingkungan sosial dan non sosial mahasiswa turut berpengaruh terhadap prestasi akademik amahasiswa.

Pentingnya dukungan ini, mengingat mahasiswa berada pada fase remaja akhir menuju fase dewasa awal dengan rentang usia antara $19-21$ tahun. Pada usia ini seseorang dapat dikatakan sebagai individu yang dewasa dan selanjutnya dianggap telah mempunyai sikap mandiri, memiliki tanggung jawab terhadap perbuatannya serta telah mampu memilih apa yang menjadi pilihannya (Mönks, dkk, 2002).

Meskipun individu telah dianggap dewasa, ada beberapa hal yang tidak dapat dihadapinya sendiri sehingga membutuhkan bantuan orang lain. Hal ini, berkaitan dengan ciri perkembangan yang terjadi pada masa remaja akhir (dewasa awal) yang merupakan periode perubahan. Perubahan-perubahan yang pada umumnya dialami remaja, antara lain; meningkatnya emosi, perubahan tubuh, minat dan peran yang diharapkan. Artinya, di satu sisi remaja menginginkan dan menuntut kebebasan, tetapi merasa takut bertanggung jawab akan akibatnya dan meragukan kemampuan dirinya untuk dapat mengatasi tanggung jawab tersebut (Usman, \& Setyawati, 2003).

Keterbatasan penelitian ini yaitu pada proses evaluasi hanya mengukur tingkat pemahaman belum pada aplikasi, akan lebih baik apabila dilanjutkan dengan memberikan perlakuan tertentu (treatment), seperti yang dijelaskan Bandura dalam Mullen (2007) bahwa peran mahasiswa dalam proses perkembangan dan pola penyesuaian pemikiran terkait pemahaman konsep SRL yang telah dimiliki perlu diarahkan pada tujuan akademis dan tindakan-tindakan yang secara reaktif dan reflektif untuk memberikan pengaruh pada situasi belajar personalnya. Sebagaimana pengetahuan dasar dan pengetahuan tersebut bertambah pada diri seseorang, selanjutnya akan bergantung pada bagaimana bentuk dan usaha untuk menjaga baik motivasi intrinsik maupun strategi pengarahan diri digunakan. Selanjutnya dijelaskan bahwa karakteristik mahasiswa khususnya yang siap dalam belajar, yaitu siswa yang memiliki keyakinan efikasi diri yang positif, kemauan, nilai-nilai, atribusiatribusi belajar, emosi-emosi, orientasi tujuan, serta suatu locus of kontrol intrisik, siap dengan tugas. untuk penelitian berikutnya perlu dicoba aplikasi konsep SRL dalam pembelajaran dengan model-model 
pembelajaran tertentu yang sesuai.

SRL bukan sekedar pemahaman atau keterampilan tentang belajar tetapi mahasiswa perlu menetapkan suatu tujuan belajar dan merancang strategi untuk mencapai tujuan yang telah ditetapkan.

\section{SIMPULAN DAN SARAN}

Hasil penelitian terhadap mahasiswa PGSD Semester II FKIP Universitas Mataram menunjukkan bahwa (1) tingkat pemahaman SRL mahasiswa PGSD tahun pertama adalah sebesar 215 (72\%), artinya tingkat pemahaman SRL mahasiswa dan terdapat pengaruh yang positif antara self regulated learning (SRL) dengan indek prestasi akademik (IP) mahasiswa. Hasil regresi sederhana menunjukkan besarnya pengaruh SRL tersebut sebesar 0,004 artinya setiap kenaikan pemahaman SRL mahasiswa 10 maka akan meningktkan IP sebesar 0,04, (2) Semakin tinggi tingkat pemahaman mahasiswa terhadap SRL maka akan semakin tinggi pula IP yang akan dicapai.

\section{DAFTAR RUJUKAN}

Abdullah, M.L. (2007). Exploring children's self regulated learning skills. Paper presented in the $1^{\text {st }}$ international conference on educational reform 2007 in Mahasarakham University, Thailand.

Auwalu, S.M., \& Norsuhaily, A.B. (2015). Relationship ofself-regulated learning and academic achievement among universiti Sultan Zainal Abidin (UniSZA) undergraduate students. Proceedings of International Conference on Empowering Islamic Civilization in the 21 st century.

Gie, T.L. (2004). Cara Belajar yang Efisien, Jilid I. Edisi Keenam. Yogyakarta: Liberty.

Heikkila, A., \& Lonka, K. (2006). Studying in higher education: students approach learning, self regulation and cognitive strategies. Studies in Higher Education, 31, 99-117.

Mukhid, A. (2009). Self-Efficacy (Perspektif Teori Kognitif Sosial dan Implikasinya terhadap Pendidikan). Tadrîs. 4(1)

Montalvo, F.T., \& Torre, M.C.G. (2004). Selfregulated learning: current and future directions. Electronic Journal of
Research in Educational Psychology, 2(1), 1-34.

Jazimah, H. 2014. Implementasi Manajemen Diri Mahasiswa dalam Pendidikan Islam. Jurnal kajian Pendidikan Islam. Vol. 6 No. 2 hal 221-250

Nicol, D.J., \& Macfarlane-Dick, D. (2006). Formative asessment and self-regulated learning: a model and seven principles of good feedback practice. Studies in Higher Education, 31, 199-218

Peverly, S.T., Brobst, K.E., Graham, M., \& Shaw, R. (2003). College adults are not good at self-regulation: a study on the relationship of self regulation, note taking, and test taking. Journal of Educational Psychology, 95, 335- 346.

Sudirman,A.A. (2015). Self-Regulated Learning dan Persepsi Dukungan Sosial dengan Prestasi Akademik Mahasiswa Fakultas Ushuluddin Iain Imam Bonjol Padang. Studia Insania, Vol 3 No 1, hal 19-34

Sugiyono. (2014). Metode Penelitian Pendidikan. Bandung: Alfabeta

Tavakolizadeh, J., \& Qavam, S.E. (2011). Effect of teaching of self-regulated learning strategies on attribution styles in student. Electronic Journal of Research in Educational Psychology, 9(3), 10871101.

Usman, M.U., \& Setyawati, L. (2003). Upaya Optimalisasi Kegiatan Belajar Mengajar. Bandung: Remaja Rosdakarya.

Yetkin, I.E.( 2006). The role of classroom context in student self-regulated learning: an exploratory case study in a sixth-grade mathematics classroom. Doctoral Dissertation.

Wangid, M.N. (2006). Kemampuan Selfregulated Learning Pada Siswa SLTPN I Bantul Yogyakarta. Disertasi tidak diterbitkan. Malang: Program Pascasarjana Universitas Negeri Malang.

Winne, P.H. (1995). Self regulation is ubiquitous but its forms vary with knowledge. Educational Psychologist, 30,223-228.

Zimmerman, B.J. (2001). Theories of selfregulated learning and academic achievement: an overview and analysis. In B.J. Zimmerman \& D.H. Schunk (eds.), Self-regulated learning and academic achievement: Theoretical 
81 | Jurnal Psikologi Pendidikan \& Konseling Vol. 2 No. 1 Juni 2016

perspectives(2nd ed., pp.1-38). Mahwah, NJ: Lawrence Erlbaum Associates, Inc.

Zimmerman, B.J., Cleary, T. \& Kitsantas, A. (2002). The Role of Observation and Emulation in the Development of Athletic Self-Regulation. Journal of Educational Psychology. Vol.92 (4), 811-817.
Zimmerman, B.J. (2008). Investigating selfregulation and motivation: historical background, methodological developments, and future prospects. AmericanEducational Research Journal, 45(1), 166-183. 